УДК 791.43-2Tarantino

\title{
LANGUAGE GAME AS MEANS OF PERSUASION (BASING ON THE FILM «INGLOURIOUS BASTERDS» BY QUENTIN TARANTINO)
}

\author{
Leslava Korenovska, doctor of philological Sciences, full professor \\ Krakow Pedagogical University, Institute of neophilology \\ malekor@op.pl
}

Colonel Landa's dialogues that include such techniques as asking important questions as if by chance, saying words of praise for the interlocutor, knowledge of foreign languages, prediction of total conversation, comparison, figures systemic, nonverbal leverage etc. are the perfect examples of the language game as a means of persuasion.

Key words: persuasion, language game, prediction of total conversation, comparison, figures systemic, nonverbal leverage.

The art of persuading, or rhetoric, is as old as the world. Plato defined rhetoric as the conquest of souls by words. Speech, words, voiced verbal signs with a certain semantics or subtext, arranged in accordance with the intent of the addressee, can cause a different reaction in thinking, views and even in the behavior of the addressee. In the XVI century, the English philosopher Francis Bacon first drew attention to the internal, subjective influences that distort the thinking of man. He called these verbal influences the deceptive ghosts of truth.

Currently, the function of language is intensively rethought. This function is reduced not only to the transmission of information. Language is increasingly seen as a system of orienting behavior [3]. The problem of language and power was developed by Roland Barth. He believed that «language, on the one hand, is the key node for socialization, on the other, has its own structure, syntax and grammar, carries a certain imperious meaning» [6, p. 345]. Valeria Chernyavskaya in the Discourse power and power of discourse focuses her attention on suggestiveness and persuasiveness. The first of these terms refers to the latent impact on the subject: the words of the addressee are perceived rather for faith, that can be regarded as some suggestion or advice. Persuasiveness (or persuasion) «means the author's influence on an addressee to an oral or a written message in order to convince of something, an appeal to improve or not to improve certain actions» [8, c. 24]. The above-mentioned author concentrates her attention on the question concerning the rational and emotionally objective aspects of ver-

(c) Korenovska L., 2017 
bal communication, in which one subject is affected by another. With such verbal manipulation, we should consider the communicative effects that the addressee directs to the recipient in order to change his views, opinion, behavior at his own discretion. In a sense, this resembles a contest of the mind and the senses, which, in turn, goes back to «Aristotle's representations in the ancient rhetoric of two levers of influence on the listener» [8, p. 24], which rely on two important and inseparable aspects of human behavior cognitive and emotional. The persuasive speech act is perceived through the prism of two communicative-pragmatic intentions: «to influence the means of the language on the consciousness of the addressee, on his opinions, evaluations; encourage him to improve certain actions, somehow change, direct his behavior» [8, c. 25]. An important role in this act of speech is played by subjective factors, or by persuasive canonical means-effects, including allegorization, comparisons, deconcretization, generalization, proverbs, quotations, etc. All these verbal levers constitute a fundamental support for persuasion. The application of communicative strategies of seduction and persuasion in the hands of a skillful addressee visually very often resembles a kind of game. We can characterize this game as the game internally tense and outwardly laid-back, light and dangerous, professionally-strategic, planned and unexpected. All this serves one purpose - «to encourage or not to perform certain postcommunicative actions» [8, c. 27]. Like every game, a game in a speech act with a persuasive nuance is also conducted according to certain rules that the sender preliminarily ponders, and ultimately chooses among the various mechanisms of persuasion, that are most effectively capable of convincing the recipient or inspiring him to perform actions, even if at the beginning of the conversation they were not taken into account by the addressee.

Speech mechanisms are characterized by an integral character and are realized taking into account emotional and rational impulses. The questions posed by the addressee play here an important role. Predominantly these are specifically lapidary questions that require an unambiguous (positive or negative) response and «imitate the interest of the addressee to the subject under discussion. They serve as an expressive means of activating the addressee: in the text they singled out the most significant semantic components. The question on behalf of the sender of the message, given in the manner that a potential recipient of information would do, expresses a special method of dialogization and intimization of the presentation. «The addressee is carried away and involved in the course of reasoning, his own background knowl- 
edge, having ideas, are activated and sent to the right channel» $[8$, p. 30]. It should be noted that the addressee must have the ability to persuade, he must influence the consciousness of the recipient through appealing to his own critical judgment, often guided by a chain of compiled and logically ordered facts and conclusions according to the purpose of the impact. Another mechanism capable of manipulating the listener's behavior is suggestion directed directly or indirectly to the psychic sphere of the recipient, thereby depriving him of a critical or logical evaluation or processing of the information received. The main emphasis is on speech and, of course, on non-verbal levers of influence (facial expressions, gestures, behavior). Speaking about the ability to influence the consciousness of a person, the question arises of the objective power authorities of the language, «which in the form of special connotative (secondary, accompanying) meanings form a hidden ideological level that is not fully realized by people, consisting of illusions and stereotypes of society» [1, p. 72-130]. Before the person arises, according to R. Barth, an «illusory» image of reality, which «substitutes» for itself the true essence of things and phenomena. Man, thus, is trapped in the linguistic space, which completely subordinates and regulates his thoughts, ideas and actions» [6, p. 345]. Introducing the concept of the split of languages into scientific usage (1973), R. Bart compares the speech act with a performance (in the theatrical sense - show) and treats it as a demonstration of arguments, methods of defense and attack, «the main weapon of which are a kind of «stable formulas», serving as the basis for a particular type of discourse» [6, p. 345].

An extensive arsenal of techniques that encompasses verbal etiquette formulas, non-verbal levers of influence, pre-conceived questions and anticipated answers, a certain decoration needed to effectively complete the conversation-manipulation, let's look at several dialogues from the film Inglourious Basterds by Quentin Tarantino. Getting acquainted with the reviews that appeared in the network immediately after the release of the film in 2009, it turned out that almost all the authors of the articles focused their attention on the history of the film, on the original combination of the events of World War II with the adventures of American heroes, on the impressions of spectators from the actors' and also on the talent of the director himself [9-11]. Unfortunately, the language of the film was not given due attention. And in vain. All eight scenes in which SS Standartenf?hrer Hans Landa (Christophe Waltz) participates as an expert orator, the organizer of the verbal representation-game with a pronounced persuasion, deserve attention 
and studies from the point of view of determining the means of persuasion. Colonel SS - a detective with a tube of Sherlock Holmes, a polyglot, an excellent speaker and a talented actor. Tarantino considered the image of Land as the most beloved in the film. While working on the film, he himself composed dialogues and personally lost those scenes in which Christophe Waltz participated to visually show the actor what the director expects from him [11]. As a born narrator and a devoted fan of the movie, Tarantino has power over the viewer, but his manipulation is devoid of a tragic hue. The director amuses the viewer with vivid dialogues from life, draws them into situations that are devoid of reasoning. The paradox of Tarantino's film is that Landa who, more than other actors, captures the attention of viewers. According to Tadeusz Sobolevsky, «Christoph Waltz gives birth to ambiguous feelings while remaining a two-valued person, ready to serve his recent enemies» [10]. In this bloody film-show Landa plays the role of jester, harlequin, clown, and plays irreproachably, masterfully and with charisma.

An example of professional language manipulation can serve as a scene of a meeting between Hans Land, nicknamed Zhidolov, with French farmer Perier La Padito (Denis Menoshe), who is suspected of harboring the Jewish family Dreyfus. The language game begins with a flattering shower of compliments from the wife and daughters of Perrier, with the shaking of the farmer's hand and the imposition of eye contact with him in order to lull the owner's vigilance and put him to him. For the observance of the etiquette of the visit, the Colonel is treated with milk - again, the words of admiration for the natural product of the farmer sound. By gaining Perier's confidence step by step, Landa starts in small doses to add to his speech important questions that require an unambiguous answer. Landa asks, for example, the names and ages of the children of the Jewish family - all in order to fulfill a bureaucratic obligation, to be sure of Padito's honesty and to close the business of his family. Innocent at first glance, the questions do not arouse the fear of the farmer, although in conversation with the Gestapo, the Frenchman keeps very restrained and a bit stiff, which can not be said of Land - he is embodied elovement and looseness. During a skilful conversation, the colonel asks permission from Perrier to switch to English. The transition to another language can be regarded as the creation of some confidential-secret encoded dialogic space in which only those involved in it understand the meaning of what has been said. As if by accident, Landa asks Perea if he knows what it is called by the pose of the eye. After receiving a response from the hunter of the Jews, Landa did not become embarrassed, 
on the contrary, he was even proud: I can think like a Jew, which is not a distinctive feature of the Germans. To induce Padito's attitude towards Jews, the colonel resorted to a comparison: the Jews are rats. At the same time, Landa unfolds a logical chain of reasoning about the dangers of these rodents: from them an infection; and if the rats had appeared in the farmer's house, he, of course, would have exterminated them, and from this the conclusion suggests that Perrier does not like rats - hence, Jews as well. A pause during the increase in the dynamism of the conversation is the shifting of attention to another object - Padito asks his guest for permission to smoke, and he loves the company with the owner and lights up a huge pipe in the spirit of Sherlock Holmes. Trying to maintain external looseness and imaginary frankness, Landa clearly informs Perrier about his duties: Duty orders me to call my people into the house and search everything. The moment of intimidation of the farmer is mitigated by the imaginary good will of the Gestapo: This can be avoided if you tell me something that will avoid punishment, an award awaits you, the German army will not bother you more. The pause lengthens, as if dying in close-up view of duel, and very eloquent and not two-valued. Realizing that the enemy is mentally liable, Landa immediately attacks him with direct questions: Are you hiding the enemies of the Reich? The answer is monosyllabic: Yes. Continuing his investigation, the SS Colonel does not ask, but rather claims that Perrier hides Jews under the floor of the house and asks only that he indicate the place. Without needing to continue the conversation and questioning, Landa gives the last instructions - asks the farmer to play him up when he again switches to French: I'm waiting for you to play along. The construction of the dialogue takes on the form of a rondo: first compliments were addressed to the ladies of Padito, and at last they are heard. Pretending that Lando and Perrier are true friends, the conversation does not end - the bullets from guns complete the last words. The skillfully played scene of obtaining the necessary information brought its results. Without much effort, through seduction, imaginary revelation, ease of behavior, the ability to master foreign languages, clear questions and an imperious nature, Lande very skillfully directed the conversation with Perrier in the right direction and achieved what he wanted.

The next scene takes place in a Parisian cafe. Hans Landa and Shoshanna Dreyfus (Melanie Laurent) are introduced to each other. As a gallant gentleman, the SS Colonel invites the girl to taste the famous strudel, ordering coffee for herself and milk for the companion. Recall: the farmer Landa himself asked for milk to put Padito in Parisian cafe he offers this product 
of the surviving daughter of the Jewish family he shot in order to show that he is much taller than Shoshanna (he drinks more refined drink - coffee); milk can be viewed here as a symbol of belonging to the lower class. The imperious behavior of the SS Colonel testifies to his dominant role in the dialogue, in which constant personal questions continue to pour: Are you the owner of the cinema?, Can you handle the projector? etc. Shortly answering the questions of the Gestapo, the girl disguises her words with a smile to seem at ease and devoid of fear. When asking questions, Landa always aims to gaze at her companion, as if trying to catch her unawares and expose her; thereby making it clear that he treats a girl as a victim of his verbal manipulation. In conversation, the Colonel constantly resorts to certain details in order to briefly distract the attention of the addressee and thereby give himself time to think about the next step. Offering Shoshanna a cigarette, Landa accidentally points to the producer's country (not French, I smoke only German), emphasizing my superiority even in material things. Next comes the abstract question that Hans asks after a long visual pause (he always looks hard at Shoshanna): I wanted to ask about something else $<\ldots>$ the pause hangs in the farm, maximally elongated. The time of silence seems to Shoshanna to be a real torture, threatening to unmask. But suddenly the tension is removed - Landa smiles and says: Probably a mere trifle, letting know that he lets go of the victim. Extinguished in whipped cream, the $\mathrm{Ge}$ stapo cigarette puts an end to the dialogue: the conversation is over, but the addressee did not receive the information he needed, so they must say goodbye and find a more suitable case for exposing the «enemies of the Reich».

Of great interest is the scene in which actress Brigitte von Hammersmark (Diane Kruger) is summoned for a verbal duel game. Dialogue in the foyer of the cinema with a beautiful woman is the skill of using a language game in manipulating of people. So, the famous actress, acting on the side of the enemies of the Reich, appears at the premiere of the film Nation's Pride, accompanied by American fighters. Bridget broke her leg in a night shootout in a cafe, so she came to the cinema with a plastered lower limb. Seeing the actress among the guests invited to the premiere, Landa immediately comes up and, out of habit, asks questions starting, of course, with compliments. Knowing the character of the Colonel, Bridget responds in a tone - the entire verbal tirade occurs with a huge internal tension, hidden under the mask of false smiles. Asking the actress about the injured leg and hearing in response that von Hammersmark was carried away by mountaineering, Landa is infectious laughter: Forgive me, dear Fraulein, I'm not laughing at 
your misfortune. What prompted you to indulge in such an absurd occupation? Then follows the chain of deductive reasoning of the Colonel: Your plaster is fresh, like mountain air. When did you climb mountains? Yesterday? While parrying Land's verbal blow, Bridget accepts the challenge game: You are observant. It happened last night. The next issue of the Gestapo can be considered the brilliance of the mind and the total defeat of the actress: And where is that mountain in Paris? A pause, hanging in the air, confusion in the eyes of von Hammersmark smoothly pass into the conspiratorial sincerity of the colonel, revealing his personal qualities: I was just teasing you. You know me. I like to tease. Transition in a conversation from one object to another is one of the favorite by the use of the actor's persuasive game.

It is not surprising that the next issue of the Gestapo is addressed to the friends of the actress. Noticing at the beginning of the conversation that her three gentlemen do not speak German - they are from Italy, Landa immediately explicates her excellent Italian: Friends of my favorite movie star will be under my personal protection. The Colonel as if casually asked if he had correctly pronounced the phrase in their native language and, having heard in response to an unambiguous answer Yes with a dubious accent, is convinced that before him the imaginary Italians.

The denouement of the growing verbal intrigue was the scene of the murder of Brigitte von Hammersmark. Asking the actress for two words, Landa invites her to Shoshanna's office, in which he hid in advance the material proof of the exposure of the movie star in his coat pocket. The last dialogue of the actress with the colonel is built in the horizontal plane: the interlocutors sit opposite each other. Attention is drawn to the visual difference between the two speakers: Landa always smiles, anticipating victory, while the whole face von Hammersmark explicates fear and horror. It should be noted that in Landa's and Bridget's conversation sounds some stable formulas that are not so much special postulates of a discursive system as conceptually neutral grammatical structures. According to Alexander Gritsanov and Marina Mozheiko, the figures of the systemic character of a certain language are formed not in content but in terms of a structural criterion: the phrase itself, being a closed syntactic structure, appears in this context as a kind of military weapon, a deterrent. As R. Barthes writes, «in every complete phrase, in its affirmative structure, there is something menacingly imperative» [6, c. 345]. The first replica of the dialogue seems an actress like familiar: Put your foot on my knee. The Colonel's request confuses Brigitte, but she obeys Hans's orderly tone. Then follows a certain 
detachment associated with the presentation of a thing without description, but with a purposeful thought to catch the enemy off guard. Put your hand in the right pocket of my cloak and give what you find there, - while uttering this phrase, The SS Colonel always stares at the actress. Taking out of her pocket her shoe, which Brigitte lost during the shootout, the actress realizes that she has finally lost. But Landa is not in a hurry to finish the game - he asks the film star to try on a shoe and only after that triumphantly exclaims: As the Americans say, what a leg. Cinderella, the ball is over. It seems, attributing to the Americans a proverb about legs, Tarantino had in mind his own admiration for the female legs (foot-fetish). Not for nothing in many of his films, close-ups were taken of his female-character's feet (eg, the feet of Uma Thurman from Kill Bill).

Often the discourse carrier in the construction of the phrase in conversation-manipulation counts on the sudden absent-mindedness of the subject, which manifests itself in incomplete, unclear phrases-answers. To play a dominant role in a conversation is to be strong, have the ability to finish their phrases to the end. According to R. Barthes, the main vocation of stable formulas of a certain language is to «include the other in our discourse as a simple object, i.e. exclude him from the community speaking a strong language and thereby ensure the absolute protection of our discourse-language environment» [6, p. 345].

The last episode, representing the skill of the actor's persecution, is a dialogue-deal scene between Hans Land and two American fighters. In conversation, the Colonel uses the means of language game discussed above: a reference to other people's words, a sudden transition from one subject to another, imaginary hospitality, and the location of the interlocutor. All these verbal devices are decorated with external psychological signs, such as: looseness, confidence in his absolute superiority over the interlocutor and conviction in the effective use of verbal manipulation. Here it is necessary to stipulate such a concept as an outrageous text, which is undoubtedly connected with behavior whose goal is «to show not so much of itself as to cause some reaction from those who see it. This behavior can manifest itself both in actions and in language» [7]. In this case outrageous text «provokes a painful reaction of the interlocutor, suggests probing the weak spots and preparing to shift the discussion from ourselves to the opponent» [7]. Landa at the beginning of the conversation deliberately teases his captives, calling the low American growth Lilliput: You, shorty, look like circus dwarfs. The incorrect tactics of the Colonel, as it turns out, does not lead to success. 
Americans do not seem to notice the mockery of Land. Instead of that, Aldo Rein (Brad Pitt) asks an abstract question about the fate of the actress. The Gestapo does not give up - he continues the verbal attack: this time he uses figures of systemic nature in the form of propositions of the subjunctive mood, which, with their content, explicate Land's bluff or his all-in game: If [highlighted by me. - LK] I will not take off the phone, you will kill the four main Fritz, and if not - end the war. Then there is the chain of logical reflections of the Gestapo: «So, let's discuss what are the chances to end the war today. The rescue of Hitler depends on my actions. And if I do not call, then his death is more of my merit than yours. [...] If you want to win the war today, we'll make a deal».

The presented Landa's long tirade gives his interlocutors time to think about the strategy of salvation. American Lieutenant Aldo Rein decides to play along with the German. To this end, he inserts short questions into Land's long sentences: what?, how many?; One-part sentences, semantically denoting agreement with the interlocutor - let's say. Aldo even agrees to contact his leadership in America and discuss the award for Land for his help in the fight against the Nazis. Amazing in its level the finest game of the SS Colonel is defeated - this time he encounters a worthy opponent, also possessing the talent of persuasion.

Episodes from the movie «Inglourious Basterds», considered from the angle of the language game as a means of persuasion, confirm the view that the main function of the language is not only to «transfer information or implement a reference to an independent reality, but also in the orientation of the individual in its own cognitive sphere $\langle\ldots\rangle$, that is, language has become more viewed as a system of orienting behavior, where the connotation plays a decisive role» [3]. Consequently, the significance of individual personality parameters in connection with this significantly increases. A language game that can manipulate the mindset, behavior and actions of the addressee contains numerous techniques, in the center of which is the word as a «peculiar window» in the linguistic consciousness of a person [4, p. 7-19]. Language becomes a tool of thinking [2, p. 75]. The ability to speak indirectly or directly, that can be regarded as some kind of aesthetic pleasure addressed to the addressee, requires mental stress, awareness of the «situation of the language game, suggesting the decoding of additional, hidden meanings» [8, p. 11]. It is a thoughtful and purposeful word framed by intonation, the tone of voice, gestures, facial expressions, a sense of humor, external signs such as ease, relaxedness and undoubted self-confidence, skillful arrange- 
ment using things with some symbolic load (milk, tube, shoe), as well as the ability to master foreign languages are the main means of persuasion in Tarantino's movie.

Cinematography, like no other kind of art, vividly represents the various strategies of persuasion, explicating the many effective means of language play. It is important to note that persuasion as a conscious effect of the author of the message on the recipient is most often marked with a negative sign. But paradoxically, Tarantino's evil attracts, intrigues and evokes sympathy. This is the skill of a talented director and the unlimited possibilities of a vast arsenal of language games, always interesting, fascinating and at the same time dangerous and dramatic. Examples of the use of persuasion in cinematography are some kind of examples of situations in which the viewer becomes a silent witness of a dialogue or audio-visually that reveals the techniques of verbal manipulation. It is important fact, that before the audience is played a spectacle with a fascinating language play of antagonists, in which one of them presents more brilliant, interesting and exciting verbal manipulation.

\section{REFERENCES}

1. Bart, R. (1994), «Myth today», Izbrannye raboty: Semiotika. Pojetika, Progress, Moscow, Russia, pp. 72-130.

2. Gluhov, V. P. (2007), Psiholingvistika. Teorija rechevoj dejatel'nosti [Psycholinguistics. Theory of speech activity], AST, Moscow, Russia.

3. Goroshko, E. I. , «Language consciousness: gender paradigm», available at : http://www.textology.ru/article.aspx?aId=43

4. Leont'ev, A. A. (1971), «Psychological structure of value», Semanticheskaja struktura slova, Nauka, Moscow, Russia, pp. 7-36.

5. Lurija, A. R. (2003), Jazyk i soznanie [Language and consciousness], Feniks, Rostov, Russia.

6. Mozhejko, M. A. (2001), Razdelenie jazykov [Division of languages], Postmodernizm. Jenciklopedija [Postmodernism. Encyclopedia], [sost. Gricanov, A. A. and Mozhejko, M. A.], Knizhnyj dom, Minsk, Belarus.

7. Repina, E. A. , «Scandalous text as text type», available at : http://www.textology.ru/article.aspx?aId=101

8. Chernjavskaja, V. E. (2012), Diskurs vlasti i vlast' diskursa. Problemy rechevogo vozdejstvija [Discourse of the power and power of a discourse. Problems of speech influence], Flinta, Moscow, Russia.

9. Jeksler, A. Recenzija na «Besslavnyh ubljudkov» [Review of «Inglourious Basterds»], available at : http://www.exler.ru/films/14-12-2009.htm 
10. Sobolewski, T. Dziwolagg Tarantino, Gazeta Wyborcza, available at : http://wyborcza.pl/duzyformat/1,127291,7015780,Dziwolag_Tarantino.html

11. Waltz C. The glorious villain in «Inglourious Basterds», Gold Derby, available at : http://goldderby.latimes.com/awards_goldderby/2009/08/inglouriousbasterds-film-news-brad-pitt-quentin-tarantino.html

\title{
ЯЗЫКОВАЯ ИГРА КАК СРЕДСТВО ПЕРСУАЗИИ (НА ПРИМЕРЕ ФИЛЬМА «БЕССЛАВНЫЕ УБЛЮДКИ» КВЕНТИНА ТАРАНТИНО)
}

\author{
Леслава Кореновська, д-р филол. наук, профессор \\ Краковский педагогический университет, Институт неофилологии
}

В статье представлен анализ многочисленных диалогов полковника СС Ганса Ланды, включающих техники персуазии. В ходе анализа выявлены следующие факторы персуазии: заранее продуманные вопросы и предвиденные ответы, завоевание расположения собеседника, убедительное внушение, личное обаяние, знание иностранных языков, меткие сравнения, фигуры системности, невербальные рычаги воздействия (жесты, мимика, поведение, тембр голоса), декорация и др. Все вышеперечисленное является яркими примерами языковой игры как средства убеждения, или персуазии.

Ключевые слова: убеждение, языковая игра, предсказание тотальной беседы, сравнение, фигуры системные, невербальное плечо.

\section{МОВНА ГРА ЯК ЗАСІБ ПЕРСУАЗІЇ (НА ПРИКЛАДІ ФІЛЬМУ «БЕЗСЛАВНІ УБЛЮДКИ» KBEHTIHA TAPAHTIHO)}

Леслава Кореновська, д-р філол. наук, професор

Краківський педагогічний університет, Інститут неофілології

У статті представлений аналіз численних діалогів полковника СС Ганса Ландi, що включають техніку персуазії. В ході аналізу виявлені наступні чинники персуазії: заздалегідь продумані питання і передбачені відповіді, завоювання симпатії співрозмовника, переконливе навіювання, особиста чарівливість, знання іноземних мов, влучні порівняння, фігури системності, невербальні важелі діі (жести, міміка, поведінка, тембр голосу), декорація та ін. Усе вищеперелічене є яскравими прикладами мовної гри як засобу переконання, або персуазії.

Ключові слова: переконання, мовна гра, пророцтво тотальної бесіди, порівняння, фігури системні, невербальне плече. 


\section{СПИСОК ВИКОРИСТАНИХ ДЖЕРЕЛ}

1. Барт Р. Миф сегодня / Р. Барт // Избранные работы: Семиотика. Поэтика. - М. : Прогресс, 1994. - С. 72-130.

2. Глухов В. П. Психолингвистика. Теория речевой деятельности / В. П. Глухов, В. А. Ковшиков. - М. : АСТ, 2007. - 318 с.

3. Горошко Е. И. Языковое сознание: гендерная парадигма [Электр. peсурс] / Е. И. Горошко. - Режим доступа к ист. : http://www.textology.ru/ article. aspx?aId $=43$

4. Леонтьев А. А. Психологическая структура значения / А. А. Леонтьев // Семантическая структура слова. - М. : Наука, 1971. - С. 7-36.

5. Лурия А. Р. Язык и сознание / А. Р. Лурия. - Ростов н/Д : Феникс, 2003. $319 \mathrm{c}$.

6. Можейко М. А. Разделение языков / М. А. Можейко // Постмодернизм : энциклопедия / [сост. А. А. Грицанов, М. А. Можейко]. - Минск : Книжный дом, 2001. - С. 783.

7. Репина Е. А. Эпатажный текст как тип текста [Электр. pесурс] / Е. А. Репина. - Режим доступа к ист. : http://www.textology.ru/article.aspx?aId=101

8. Чернявская В. Е. Дискурс власти и власть дискурса. Проблемы речевого воздействия : [учеб. пос.] / В. Е. Чернявская. - М. : Флинта, 2012. - 128 с.

9. Экслер А. Рецензия на «Бесславных ублюдков» [Электр. ресурс] / Алекс Экслер. - Режим доступа к ист. : http://www.exler.ru/films/14-12-2009. htm

10. Sobolewski T. Dziwoląg Tarantino / Tadeusz Sobolewski // Gazeta Wyborcza. Available at : http://wyborcza.pl/duzyformat/1,127291,7015780,Dziwolag Tarantino.html

11. Waltz C. The glorious villain in «Inglourious Basterds». Gold Derby / Christoph Waltz. - Available at : http://goldderby.latimes.com/awards_goldderby/2009/08/inglourious-basterds-film-news-brad-pitt-quentin-tarantino.html 